\title{
Erythrobacter pelagi sp. nov., a member of the family Erythrobacteraceae isolated from the Red Sea
}

\author{
Correspondence \\ Pei-Yuan Qian \\ boqianpy@ust.hk
}

\author{
Hui-xian Wu, ${ }^{1,2}+$ Pok Yui Lai, ${ }^{1} \dagger$ On On Lee, ${ }^{1}$ Xiao-jian Zhou, ${ }^{3}$ Li Miao, ${ }^{3}$ \\ Hao Wang ${ }^{1}$ and Pei-Yuan Qian ${ }^{1}$ \\ ${ }^{1}$ KAUST Global Partnership Program, Division of Life Science, Hong Kong University of Science \\ and Technology, Clear Water Bay, Hong Kong \\ ${ }^{2}$ College of Fisheries and Life Science, Shanghai Ocean University, Shanghai, PR China \\ ${ }^{3}$ Institute of Marine Science and Technology, Yangzhou University, No. 196, West Huayang Street, \\ Yangzhou City, Jiangsu Province, PR China
}

\begin{abstract}
A novel Gram-negative, aerobic, catalase- and oxidase-positive, non-sporulating, non-motile, rodshaped bacterium, designated strain UST081027-248 ${ }^{\top}$, was isolated from seawater of the Red Sea. Phylogenetic analysis based on 16S rRNA gene sequences showed that strain UST081027-248 ${ }^{\top}$ fell within the genus Erythrobacter. Levels of $16 \mathrm{~S}$ rRNA gene sequence similarity between the novel strain and the type strains of Erythrobacter species ranged from 95.3\% (with Erythrobacter gangjinensis) to $98.2 \%$ (with Erythrobacter citreus). However, levels of DNA-DNA relatedness between strain UST081027-248 ${ }^{\top}$ and the type strains of closely related species were below $70 \%$. Optimal growth of the isolate occurred in the presence of $2.0 \% \mathrm{NaCl}$, at $\mathrm{pH} 8.0-9.0$ and at $28-36{ }^{\circ} \mathrm{C}$. The isolate did not produce bacteriochlorophyll $a$. The predominant cellular fatty acids were $C_{17: 1} \omega 6 c$, summed feature $8\left(C_{18: 1} \omega 6 c\right.$ and/or $\left.\mathrm{C}_{18: 1} \omega 7 \mathrm{c}\right)$ and $\mathrm{C}_{15: 0}$ 2-OH. The genomic DNA G+C content of strain UST081027-248 ${ }^{\top}$ was $60.4 \mathrm{~mol} \%$. Phenotypic properties and phylogenetic distinctiveness clearly indicated that strain UST081027-248 ${ }^{\top}$ represents a novel species of the genus Erythrobacter, for which the name Erythrobacter pelagi sp. nov. is proposed. The type strain is UST081027-248 ${ }^{\top}(=\mathrm{JCM}$ $17468^{\top}=$ NRRL $59511^{\top}$ ).
\end{abstract}

The genus Erythrobacter, proposed by Shiba \& Simidu (1982), belongs to the family Erythrobacteraceae (Lee et al., 2005), which contains three other genera, Altererythrobacter (Kwon et al., 2007), Porphyrobacter (Fuerst et al., 1993) and Erythromicrobium (Lee et al., 2005). Most members of the family have been isolated from aquatic environments such as freshwater, seawater, marine mats or marine sediment; members of the genus Erythrobacter have been solely isolated from marine habitats. All members of the genus Erythrobacter produce pigments and some produce bacteriochlorophyll (BChl) $a$. At the time of writing, the genus comprised ten recognized species: Erythrobacter longus (Shiba \& Simidu, 1982), E. litoralis (Yurkov et al., 1994), E. citreus (Denner et al., 2002), E. flavus (Yoon et al., 2003), E. aquimaris (Yoon et al., 2004), E. seohaensis (Yoon et al., 2005), E. gaetbuli (Yoon et al., 2005), E. vulgaris (Ivanova et al., 2005), E.

†These authors contributed equally to this study.

Abbreviation: BChl a, bacteriochlorophyll a.

The GenBank/EMBL/DDBJ accession number for the 16S rRNA gene sequence of strain UST081027-248 ${ }^{\top}$ is HQ203045.

Two supplementary figures are available with the online version of this paper. nanhaisediminis (Xu et al., 2010) and E. gangiinensis (Lee et al., 2010). In the present study, a novel, slightly halophilic, orange-pigmented strain, designated UST081027-248 ${ }^{\mathrm{T}}$, isolated from the Red Sea is described. On the basis of polyphasic analysis of phenotypic and phylogenetic data, we propose that strain UST081027-248 ${ }^{\mathrm{T}}$ represents a novel species of the genus Erythrobacter.

During a study of the bacterial diversity and resources of brine pools in the Red Sea and the seawater lying above them, strain UST081027-248 ${ }^{\mathrm{T}}$ was isolated from a seawater sample. The sample was collected in October 2008 with a Niskin bottle at $20 \mathrm{~m}$ water depth above the Discovery Deep brine pool $\left(21^{\circ} 16.976^{\prime} \mathrm{N} 38^{\circ} 02.985^{\prime} \mathrm{E}\right)$. Strain UST081027- $248^{\mathrm{T}}$ was isolated by the standard dilutionplating technique on marine agar 2216 (MA; Difco) and incubated at room temperature $\left(25^{\circ} \mathrm{C}\right)$. The strain was purified by repeated streaking and observed under a light microscope (Leica MZ6). The purified strain was stored at $-80{ }^{\circ} \mathrm{C}$ in marine broth 2216 (MB; Difco) with $30 \%$ $(\mathrm{v} / \mathrm{v})$ glycerol. Unless otherwise specified, all characteristics described hereafter were based on cultures incubated on $\mathrm{MA}$ or in $\mathrm{MB}$ for 3 days at room temperature. E. aquimaris JCM $12189^{\mathrm{T}}$ and E. nanhaisediminis JCM $16125^{\mathrm{T}}$, obtained 
from the Japan Collection of Microorganisms (JCM), E. longus DSM $6997^{\mathrm{T}}$, E. citreus DSM $14432^{\mathrm{T}}$, E. flavus DSM $16421^{\mathrm{T}}, E$. seohaensis DSM $16221^{\mathrm{T}}$ and E. vulgaris DSM $17792^{\mathrm{T}}$, obtained from the German Collection of Microorganisms and Cell Cultures (DSMZ), were cultured under the same conditions for comparison.

Cell morphology was determined by using light microscopy and transmission electron microscopy (Tecnai 12). Gram staining was performed according to Collins et al. (1989). Gliding and swimming motility were observed under a phase-contrast light microscope (Olympus BX51; $100 \times$ magnification) after growing the isolate on $\mathrm{MB}$ solidified with $0.4 \%$ agar (Bowman, 2000). The presence of BChl $a$ was determined based on the absorption spectrum of the methanol extract of cells according to Yoon et al. (2003).

Genomic DNA was extracted from the cells by using the MiniBEST Bacterial Genomic DNA Extraction kit (TaKaRa). The 16S rRNA gene of UST081027-248 ${ }^{\mathrm{T}}$ was amplified by using primer pair $8 \mathrm{~F}\left(5^{\prime}\right.$-AGAGTTTGATCCTGGCTCAG-3') and 1525R (5'-AAGGAGTGWTCCARCC-3') (Shrout et al., 2005) with Vent DNA polymerase (NEB) and was sequenced by using an Applied Biosystems 3100 automated DNA sequencer as previously described (Lau et al., 2005). The resulting 16S rRNA gene sequence was compared with sequences obtained from GenBank by using BLAST searches (Altschul et al., 1997) to determine its approximate phylogenetic position. Sequences of the novel isolate and those of related species were aligned with CLUSTAL X (Thompson et al., 1997), and then manually edited with the BioEdit sequence alignment editor. Phylogenetic analysis was performed by using the software package MEGA version 5.0 (Tamura et al., 2011). Evolutionary distances were computed according to Kimura's two-parameter model (Kimura, 1980) and phylogenetic trees were generated by using the neighbour-joining (Saitou \& Nei, 1987), maximum-likelihood (Felsenstein, 1981) and minimum-evolution (Felsenstein, 1997) methods. Bootstrap analysis was used to evaluate the tree topology of the neighbour-joining data by means of 1000 resamplings (Felsenstein, 1985). DNA-DNA hybridization was performed in triplicate by using the membrane filter method as described by Denhardt (1966) and De Ley \& Tijtgat (1970) with the modifications suggested by Cano et al. (1992). The DNA $\mathrm{G}+\mathrm{C}$ content was determined by using the HPLC method performed in triplicate (Mesbah et al., 1989).

For determination of the cellular fatty acid composition, cells were grown in $\mathrm{MB}$ in flasks on a rotary shaker (220 r.p.m.) at $30{ }^{\circ} \mathrm{C}$ for 3 days and the fatty acids were then extracted and methylated as described by Sasser (1990). The profile of methylated fatty acids was determined by using the MIDI Sherlock Microbial Identification System (Microbial ID, Sherlock version 6.1, TSBA6 method). Polar lipids were extracted and analysed on silica gel plates (Kieselgel $60 \mathrm{~F}$; Merck) by two-dimensional TLC (Kates, 1986). Polar lipids from E. citreus DSM $14432^{\mathrm{T}}$, E. seohaensis DSM $16221^{\mathrm{T}}$ and E. nanhaisediminis JCM $16125^{\mathrm{T}}$ were used as reference strains. Respiratory lipoquinones were extracted and analysed by HPLC (Collins, 1985). Ubiquinone-10 (Q-10) from Sigma was used as a reference.

The phenotypic characteristics of strain UST081027-248 ${ }^{\mathrm{T}}$, including growth conditions, hydrolysis of various substrates, susceptibility to antibiotics, reduction of nitrate, production of $\mathrm{H}_{2} \mathrm{~S}$, enzymes, indole and acetoin, and utilization of and acid production from carbon sources, were tested. The requirement of oxygen for growth was examined by using the Oxoid anaerobic system on YP-SW agar (Lau et al., 2005). Growth at $4-52{ }^{\circ} \mathrm{C}$ and $\mathrm{pH} 5.0-10.0$ ( $\mathrm{pH}$ adjusted with $1 \mathrm{M} \mathrm{HCl}$ or $\mathrm{NaOH}$ ) was observed after up to 8 days of incubation. The requirement for and tolerance to various salt concentrations were tested on $1.2 \%$ agar medium containing (per litre) $5.9 \mathrm{~g} \mathrm{MgCl}_{2}$, $3.24 \mathrm{~g} \mathrm{Na}_{2} \mathrm{SO}_{4}, 1.8 \mathrm{~g} \mathrm{CaCl}_{2}, 0.55 \mathrm{~g} \mathrm{KCl}, 5.0 \mathrm{~g}$ peptone, $0.1 \mathrm{~g}$ ferric citrate and $1.0 \mathrm{~g}$ yeast extract $(\mathrm{pH} 7.6)$ in the presence of $0-18 \%(\mathrm{w} / \mathrm{v}) \mathrm{NaCl}$ (intervals of $1 \%$ ) (ZoBell, 1941). Sensitivity to kanamycin $(30 \mu \mathrm{g})$, tetracycline $(30 \mu \mathrm{g})$, ampicillin $(30 \mu \mathrm{g})$, chloramphenicol $(30 \mu \mathrm{g})$, streptomycin $(30 \mu \mathrm{g})$ and penicillin (20 IU) were tested by using the method described by Acar (1980). Catalase and oxidase activities were determined as described by Chen et al. (2007). Hydrolysis of Tween 80, starch and gelatin were determined according to Smibert \& Krieg (1994). Other enzyme activities, substrate utilization patterns, nitrate reduction and production of $\mathrm{H}_{2} \mathrm{~S}$, indole and acetoin were tested by using the API 20E, API 20NE, API 50CH and API ZYM commercial systems (bioMérieux) according to the manufacturer's instructions, with $2.2 \% \mathrm{NaCl}$ salt in the suspension (MacDonell et al., 1982). Growth on formate, glycerol, dextrin, succinate, lactate, L-alanine, maltose, sucrose, Dsorbitol, D-galactose, starch, pyruvate, D-glutamate and Dglucose as sole carbon sources was also tested by using medium containing $0.2 \mathrm{~g} \mathrm{NaNO}_{3}, 0.2 \mathrm{~g} \mathrm{NH}_{4} \mathrm{Cl}, 0.05 \mathrm{~g}$ yeast extract and $0.4 \%(\mathrm{w} / \mathrm{v})$ carbon source per litre of artificial seawater at $3.5 \%$ salinity (Nedashkovskaya et al., 2003).

Cells of strain UST081027-248 ${ }^{\mathrm{T}}$ were Gram-negative, long rods $(2.5-3.0 \mu \mathrm{m}$ long and $0.5-0.6 \mu \mathrm{m}$ wide) (see Fig. S1 in IJSEM Online) that grew only under aerobic conditions and showed no gliding or flagellar motility. Pure colonies were orange, raised and circular (1.5-2.5 $\mathrm{mm}$ in diameter) with an entire edge and smooth surface. BChl $a$ was absent. Detailed physiological and biochemical characteristics of strain UST081027-248 ${ }^{\mathrm{T}}$ are listed in Table 1 and in the species description below.

Phylogenetic analysis of the nearly complete 16S rRNA gene sequence (1453 bp) showed that strain UST081027-248 ${ }^{\mathrm{T}}$ exhibited closest affiliation with species of the genus Erythrobacter, family Erythrobacteraceae. Levels of $16 \mathrm{~S}$ rRNA gene sequence similarity between strain UST081027$248^{\mathrm{T}}$ and the type strains of recognized Erythrobacter species ranged from $95.3 \%$ (with E. ganginensis) to $98.2 \%$ (with $E$. citreus). In the neighbour-joining phylogenetic tree based on $16 \mathrm{~S}$ rRNA gene sequences, strain UST081027-248 ${ }^{\mathrm{T}}$ was closely related to members of the genus Erythrobacter (Fig. 1). Similar tree topologies were also found in the 
Table 1. Differential phenotypic characteristics between strain UST081027-248 ${ }^{\top}$ and the type strains of phylogenetically related Erythrobacter species.

Strains: 1, UST081027-248 ${ }^{\mathrm{T}}$; 2, E. citreus RE35F/1 ${ }^{\mathrm{T}}$ (data from Denner et al., 2002, except where indicated); 3, E. aquimaris SW-110 ${ }^{\mathrm{T}}$ (Yoon et al., 2004); 4, E. flavus SW-46 ${ }^{\mathrm{T}}$ (Yoon et al., 2003); 5, E. seohaensis SW-135 ${ }^{\mathrm{T}}$ (Yoon et al., 2005); 6, E. vulgaris 022-2-10 ${ }^{\mathrm{T}}$ (Ivanova et al., 2005); 7 , E. longus $\mathrm{OCh}_{101}^{\mathrm{T}}$ (Yoon et al., 2003); 8, E. nanhaisediminis $\mathrm{T} 30^{\mathrm{T}}$ (Xu et al., 2010). All strains are susceptible to chloramphenicol but resistant to streptomycin, and catalase- and oxidase-positive.

\begin{tabular}{|c|c|c|c|c|c|c|c|c|}
\hline Characteristic & $1^{\star}$ & 2 & 3 & 4 & 5 & 6 & 7 & 8 \\
\hline Colony colour & Orange & Yellow & Orange & Yellow & Orange-yellow & Yellow & Orange & Orange \\
\hline Motility & - & - & - & + & - & - & + & + \\
\hline Presence of BChl $a$ & - & - & - & - & - & - & + & - \\
\hline Nitrate reduction ${ }^{\star}$ & + & + & - & - & - & - & + & - \\
\hline Tolerance to $\mathrm{NaCl}(\%)$ & 8 & 10 & 10 & 14 & 9 & 8 & 8 & 10 \\
\hline \multicolumn{9}{|l|}{ Hydrolysis of: ${ }^{*}$} \\
\hline Gelatin & - & $-\dagger$ & - & - & - & - & + & - \\
\hline Starch & - & $-\dagger$ & + & + & - & - & - & - \\
\hline Tween 80 & - & $-\dagger$ & $+\dagger$ & $+\dagger$ & $+\dagger$ & + & + & + \\
\hline \multicolumn{9}{|l|}{ Utilization of:* } \\
\hline D-Glucose & + & + & + & - & + & - & + & + \\
\hline Fructose & + & - & - & - & - & - & $-\dagger$ & - \\
\hline Acetate & + & + & + & + & + & $-\dagger$ & + & + \\
\hline Citrate & - & + & - & - & - & - & + & - \\
\hline Pyruvate & + & - & + & + & + & - & + & $+\dagger$ \\
\hline Glutamate & + & + & - & - & - & - & + & $+\dagger$ \\
\hline Succinate & + & $+\dagger$ & + & - & + & + & - & + \\
\hline Malate & + & - & + & - & - & - & - & + \\
\hline Lactate & - & - & - & + & - & - & - & - \\
\hline Maltose & + & - & - & + & - & - & + & + \\
\hline Sucrose & + & - & - & - & + & - & + & - \\
\hline \multicolumn{9}{|l|}{ Susceptibility to:* } \\
\hline Ampicillin & + & - & $-\dagger$ & $-\dagger$ & $-\dagger$ & $-\dagger$ & $+\dagger$ & $-\dagger$ \\
\hline Tetracycline & + & - & $-\dagger$ & $-\dagger$ & $-\dagger$ & - & - & $-\dagger$ \\
\hline Kanamycin & + & - & $-\dagger$ & $+\dagger$ & $-\dagger$ & $+\dagger$ & $-\dagger$ & - \\
\hline $\begin{array}{l}\text { Growth temperature range } \\
\left({ }^{\circ} \mathrm{C}\right)^{*}\end{array}$ & $12-40$ & $4-37$ & $10-41$ & $10-42$ & $10-40$ & $10-40$ & $10-35 \dagger$ & $4-45$ \\
\hline $\begin{array}{l}\text { DNA G }+C \text { content } \\
(\mathrm{mol} \%)\end{array}$ & 60.4 & 62.0 & 62.2 & 64.0 & 62.2 & $61-62$ & 60.7 & 59.5 \\
\hline
\end{tabular}

${ }^{\star}$ Data are from this study.

$\dagger$ Data absent or different from previous studies.

trees constructed with the minimum-evolution and maximum-likelihood algorithms. The closest relatives of strain UST081027-248 ${ }^{\mathrm{T}}$ were the type strains of E. citreus $(98.2 \%$ 16S rRNA gene sequence similarity), E. vulgaris $(97.7 \%)$, E. flavus $(97.5 \%)$, E. nanhaisediminis $(97.3 \%)$ and E. seohaensis $(97.2 \%)$. However, the results of DNA-DNA hybridization experiments demonstrated that strain UST081027$248^{\mathrm{T}}$ represented a novel species in the genus, with levels of relatedness of the novel strain to the type strains of the above species being below $70 \%$. Mean levels of DNA-DNA relatedness between strain UST081027-248 ${ }^{\mathrm{T}}$ and E. citreus DSM $14432^{\mathrm{T}}$, E. vulgaris DSM $17792^{\mathrm{T}}$, E. flavus DSM $16421^{\mathrm{T}}$, E nanhaisediminis DSM $16125^{\mathrm{T}}$ and E. seohaensis DSM $16221^{\mathrm{T}}$ were $62,14,24,14$ and $48 \%$, respectively, with a standard deviation of $2.5 \%$. The DNA G + C content of strain UST081027- $248^{\mathrm{T}}$ was $60.4 \mathrm{~mol} \%$ (Table 1 ), which was within the range previously found for recognized species in the genus Erythrobacter (59.5-67.0 mol\%).

The cellular fatty acid composition of UST081027-248 was similar to that of the reference strains in the genus, with a very high proportion of unsaturated fatty acids, $\mathrm{C}_{17: 1} \omega 6 c$, summed feature $8\left(\mathrm{C}_{18: 1} \omega 6 c\right.$ and/or $\left.\mathrm{C}_{18: 1} \omega 7 c\right)$, and the hydroxyl fatty acid $\mathrm{C}_{15: 0} 2-\mathrm{OH}$. However, the content of $\mathrm{C}_{17: 1} \omega 6 \mathrm{c}$ in strain UST081027-248 ${ }^{\mathrm{T}}$ was fourfold higher than in the reference strains, whereas the content of summed feature 8 was only half that of the reference strains. Therefore, strain UST081027-248 ${ }^{\mathrm{T}}$ shared common major cellular fatty acids with members of the genus Erythrobacter but was subtly different in certain components. The detailed cellular fatty acid composition of strain UST081027-248 ${ }^{\mathrm{T}}$ is shown in Table 2. The major polar lipids were similar to those of the reference strains 


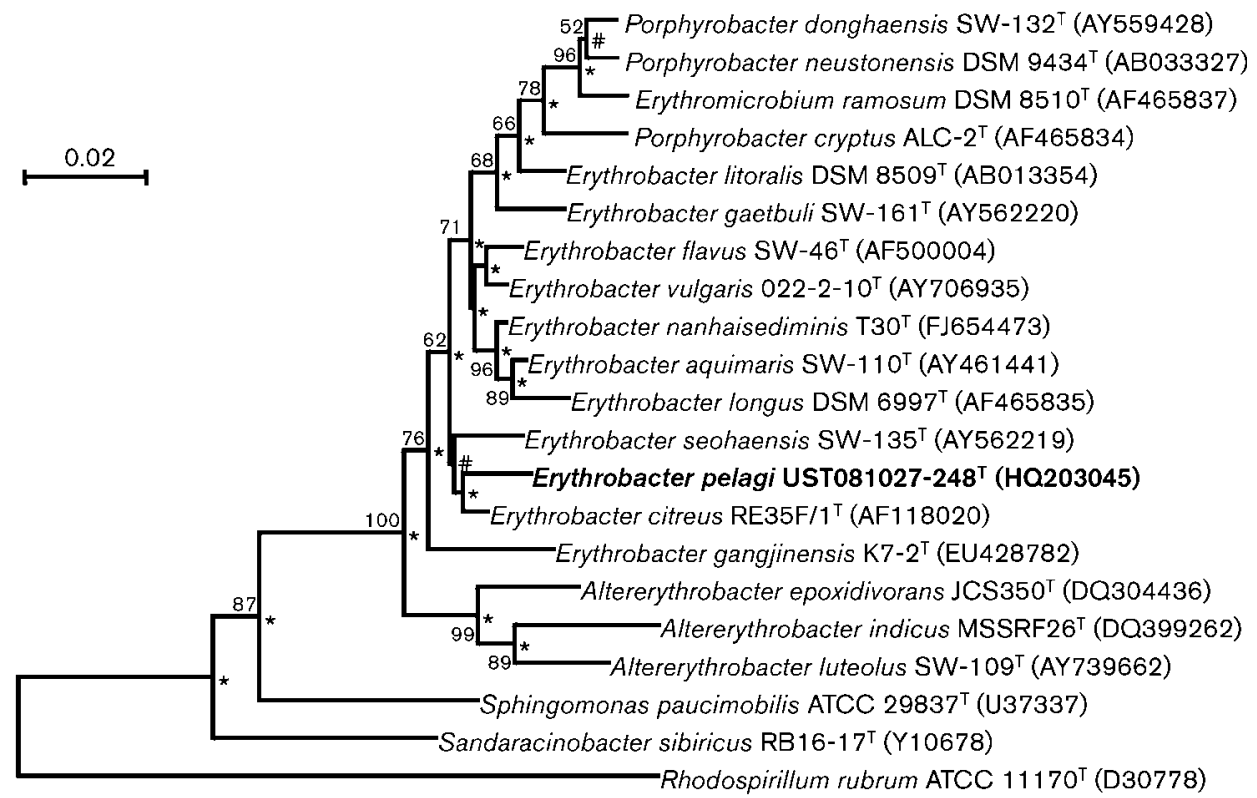

Fig. 1. Neighbour-joining phylogenetic tree based on 16S rRNA gene sequences showing the position of strain UST081027$248^{\top}$ among related taxa. Numbers at nodes are bootstrap values (percentages of 1000 resamplings); only values $>50 \%$ are shown. Asterisks indicate nodes that are also found with both the maximum-likelihood and the minimum-evolution methods; hashes indicate nodes that are also found with the minimum-evolution method. Rhodospirillum rubrum ATCC $11170^{\top}$ was used as an outgroup. Bar, 0.02 substitutions per site.

and were identified as phosphatidylcholine, phosphatidylethanolamine, diphosphatidylglycerol and phosphatidylglycerol (Fig. S2). The predominant lipoquinone was ubiquinone Q-10.

On the basis of the data presented, strain UST081027$248^{\mathrm{T}}$ is clearly a member of the genus Erythrobacter but is distinguishable from all described species in this genus. Therefore, strain UST081027- $248^{\mathrm{T}}$ is considered to represent a novel species of the genus Erythrobacter, for which the name Erythrobacter pelagi sp. nov. is proposed.

\section{Description of Erythrobacter pelagi sp. nov.}

Erythrobacter pelagi (pe'la.gi. L. gen. n. pelagi of/from the sea, reflecting isolation of the type strain from seawater of the Red Sea).

Cells are Gram-negative, long rods $(2.5-3.0 \mu \mathrm{m}$ long and $0.5-0.6 \mu \mathrm{m}$ wide) (Fig. S1) that grow only under aerobic conditions. No gliding or flagellar motility. Colonies grown on $\mathrm{MA}$ at $28{ }^{\circ} \mathrm{C}$ for 5 days are orange, $1.5-2.5 \mathrm{~mm}$ in diameter, circular and convex with a smooth surface and an entire edge. Flexirubin-type or diffusible pigments are not produced. Optimal $\mathrm{pH}$ for growth is 8.0-9.0; no growth is observed below $\mathrm{pH} 5.0$ or above $\mathrm{pH} 10.0$. Growth occurs at $10-42{ }^{\circ} \mathrm{C}$ (optimal, $20-36{ }^{\circ} \mathrm{C}$ ). Optimal growth occurs in the presence of $2-3 \%(\mathrm{w} / \mathrm{v}) \mathrm{NaCl}$; growth does not occur in the absence of $\mathrm{NaCl}$ or above $10 \%(\mathrm{w} / \mathrm{v})$ $\mathrm{NaCl}$. Cells do not produce BChl $a$. Does not hydrolyse DNA, gelatin, aesculin, starch, casein, cellulose or Tween
80. Positive for indole production and nitrate reduction, but negative for $\mathrm{H}_{2} \mathrm{~S}$ production. Positive for catalase, oxidase, alkaline phosphatase, esterase lipase (C8), trypsin, valine arylamidase, $\alpha$-chymotrypsin, naphthol-AS-BI-phosphohydrolase, $\alpha$-glucosidase, leucine arylamidase and acid phosphatase, and weakly positive for esterase (C4) and cystine arylamidase. Negative for lipase (C14), urease, $\mathrm{N}$ acetyl- $\beta$-glucosaminidase, arginine dihydrolase, lysine decarboxylase, ornithine decarboxylase, $\alpha$-galactosidase, $\beta$ galactosidase, $\beta$-glucuronidase, $\beta$-glucosidase, $\alpha$-mannosidase, $\alpha$-fucosidase, gelatinase and tryptophan deaminase activities. Acid is produced from L-sorbose, L-arabinose, inositol, D-rhamnose, D-sorbitol, dulcitol, D-fructose, Dgalactose, D-glucose, D-ribose, D-xylose and D-mannitol, but not from fucose, erythritol, amygdalin, methyl $\beta$-Dxylopyranoside, melezitose, starch, arbutin, salicin, cellobiose, inulin, xylitol, gentiobiose, glycogen, turanose, citrate, D-lyxose, D-tagatose or arabitol. Utilization of glycerol, pyruvate, glutamate, succinate, maltose, sucrose, dextrin and L-alanine as sole carbon sources is observed on agar medium supplemented with $0.4 \%(\mathrm{w} / \mathrm{v})$ carbon source while utilization of D-glucose, adonitol, $N$ acetylglucosamine, aesculin, lactose, maltose, melibiose, sucrose, trehalose and raffinose is observed in the API $20 \mathrm{E}$ and $50 \mathrm{CH}$ systems. No utilization of formate, starch or lactate is observed. Susceptible to chloramphenicol, kanamycin, tetracycline, ampicillin and penicillin, but resistant to streptomycin. The predominant fatty acids are $\mathrm{C}_{17: 1} \omega 6 c$, summed feature $8\left(\mathrm{C}_{18: 1} \omega 6 c\right.$ and/or $\left.\mathrm{C}_{18: 1} \omega 7 c\right)$ 
Table 2. Cellular fatty acid compositions (\%) of strain UST081027-248 ${ }^{\top}$ and reference type strains of Erythrobacter species

Strains: 1 , UST081027-248 ${ }^{\mathrm{T}} ; 2$, E. citreus DSM $14432^{\mathrm{T}} ; 3$, E. seohaensis DSM $16221^{\mathrm{T}} ; 4$, E. vulgaris DSM $17792^{\mathrm{T}} ; 5$, E. longus DSM $6997^{\mathrm{T}} ; 6$, E. nanhaisediminis DSM $16125^{\mathrm{T}}$. Only fatty acids with a relative abundance of more than $0.5 \%$ in any of the strains are shown. -, Not detected. All data are from this study.

\begin{tabular}{|c|c|c|c|c|c|c|}
\hline Fatty acid & 1 & 2 & 3 & 4 & 5 & 6 \\
\hline \multicolumn{7}{|l|}{ Straight-chain } \\
\hline $\mathrm{C}_{14: 0}$ & - & - & 0.4 & 0.4 & - & 0.6 \\
\hline $\mathrm{C}_{16: 0}$ & 4.1 & 5.7 & 5.3 & 3.7 & 4.7 & 8.3 \\
\hline $\mathrm{C}_{17: 0}$ & 1.5 & - & - & 1.4 & 1.6 & 0.7 \\
\hline $\mathrm{C}_{18: 0}$ & 1.3 & 0.9 & 0.3 & 0.2 & 0.6 & 0.6 \\
\hline \multicolumn{7}{|l|}{ Branched } \\
\hline iso- $\mathrm{C}_{17: 0}$ & - & 1.2 & - & - & 1.8 & - \\
\hline \multicolumn{7}{|l|}{ Unsaturated } \\
\hline $\mathrm{C}_{16: 1} \omega 5 c$ & - & 1.7 & 1.2 & - & - & 0.7 \\
\hline $\mathrm{C}_{17: 1} \omega 6 c$ & 39.2 & 9.0 & 9.6 & 3.9 & 3.2 & 9.7 \\
\hline $\mathrm{C}_{17: 1} \omega 8 c$ & 4.1 & 0.8 & 1.2 & 2.2 & 4.8 & 1.0 \\
\hline $\mathrm{C}_{18: 1} \omega 5 c$ & - & 1.8 & 0.5 & - & - & 1.0 \\
\hline $\mathrm{C}_{18: 1} \omega 9 c$ & 1.6 & - & - & - & - & 1.0 \\
\hline 11-Methyl $\mathrm{C}_{18: 1} \omega 7 c$ & - & 3.2 & 2.1 & 2.4 & - & 6.1 \\
\hline \multicolumn{7}{|l|}{ Hydroxy } \\
\hline $\mathrm{C}_{13: 0} 2-\mathrm{OH}$ & 2.2 & - & - & - & 1.4 & - \\
\hline $\mathrm{C}_{14: 0} 2-\mathrm{OH}$ & 5.1 & 2.9 & 7.1 & 5.2 & 9.0 & 8.2 \\
\hline $\mathrm{C}_{15: 0} 2-\mathrm{OH}$ & 10.6 & 1.8 & 1.6 & 6.6 & 8.3 & 5.2 \\
\hline $\mathrm{C}_{16: 0} 2-\mathrm{OH}$ & - & 3.5 & 0.9 & 0.9 & 0.6 & 2.2 \\
\hline $\mathrm{C}_{16: 1} 2-\mathrm{OH}$ & - & - & 0.4 & 1.3 & - & - \\
\hline $\mathrm{C}_{18: 1} 2-\mathrm{OH}$ & - & 0.9 & 0.7 & 1.0 & - & 0.8 \\
\hline iso- $\mathrm{C}_{16: 0} 3-\mathrm{OH}$ & - & 1.5 & 0.5 & - & - & 0.8 \\
\hline \multicolumn{7}{|l|}{ Summed features ${ }^{\star}$} \\
\hline 3 & 2.4 & 8.8 & 16.5 & 12.7 & - & 5.8 \\
\hline 8 & 28.1 & 56.5 & 51.7 & 58.2 & 64.1 & 46.5 \\
\hline
\end{tabular}

${ }^{*}$ Summed feature 3 comprises $\mathrm{C}_{16: 1} \omega 6 c$ and/or $\mathrm{C}_{16: 1} \omega 7 c$; summed feature 8 comprises $\mathrm{C}_{18: 1} \omega 6 c$ and/or $\mathrm{C}_{18: 1} \omega 7 c$.

and $\mathrm{C}_{15: 0}$ 2-OH. Major polar lipids are phosphatidylcholine, phosphatidylethanolamine, diphosphatidylglycerol and phosphatidylglycerol while the predominant respiratory lipoquinone is ubiquinone Q-10.

The type strain, UST081027-248 ${ }^{\mathrm{T}}\left(=\mathrm{JCM} 17468^{\mathrm{T}}=\mathrm{NRRL}\right.$ $\left.59511^{\mathrm{T}}\right)$, was isolated from shallow seawater collected from the middle of the Red Sea. The DNA G + C content of the type strain is $60.4 \mathrm{~mol} \%$.

\section{Acknowledgements}

We are grateful to the captain and crew of the R/V Oceanus for providing technical help during sampling. This study was supported by grants from the KAUST Global Partnership Program (KAUST005CML07/08) to P.-Y.Q. and from Leading Academic Discipline Project of Shanghai Municipal Education Commission (J50701) to H.-x. W.

\section{References}

Acar, J. F. (1980). The disc susceptibility test. In Antibiotics in Laboratory Medicine, pp. 24-54. Edited by V. Lorian. Baltimore, MD: Williams \& Wilkins.

Altschul, S. F., Madden, T. L., Schäffer, A. A., Zhang, J., Zhang, Z., Miller, W. \& Lipman, D. J. (1997). Gapped BLAST and PSI-BLAST: a new generation of protein database search programs. Nucleic Acids Res 25, 3389-3402.

Bowman, J. P. (2000). Description of Cellulophaga algicola sp. nov., isolated from the surfaces of Antarctic algae, and reclassification of Cytophaga uliginosa (ZoBell and Upham 1944) Reichenbach 1989 as Cellulophaga uliginosa comb. nov. Int J Syst Evol Microbiol 50, 18611868.

Cano, R. J., Torres, M. J., Klem, R. E. \& Palomares, J. C. (1992). DNA hybridization assay using ATTOPHOS, a fluorescent substrate for alkaline phosphatase. Biotechniques 12, 264-269.

Chen, Y. G., Cui, X. L., Pukall, R., Li, H. M., Yang, Y. L., Xu, L. H., Wen, M. L., Peng, Q. \& Jiang, C. L. (2007). Salinicoccus kunmingensis sp. nov., a moderately halophilic bacterium isolated from a salt mine in Yunnan, south-west China. Int J Syst Evol Microbiol 57, 2327-2332.

Collins, M. D. (1985). Analysis of isoprenoid quinones. Methods Microbiol 18, 329-366.

Collins, C. H., Lyne, P. M. \& Grange, J. M. (1989). Collins and Lyne's Microbiological Methods. London: Butterworths.

De Ley, J. \& Tijtgat, R. (1970). Evaluation of membrane filter methods for DNA-DNA hybridization. Antonie van Leeuwenhoek 36, 461-474.

Denhardt, D. T. (1966). A membrane-filter technique for the detection of complementary DNA. Biochem Biophys Res Commun 23, 641-646.

Denner, E. B. M., Vybiral, D., Koblizek, M., Kämpfer, P., Busse, H. J. \& Velimirov, B. (2002). Erythrobacter citreus sp. nov., a yellowpigmented bacterium that lacks bacteriochlorophyll $a$, isolated from the western Mediterranean Sea. Int J Syst Evol Microbiol 52, 16551661.

Felsenstein, J. (1981). Evolutionary trees from DNA sequences: a maximum likelihood approach. J Mol Evol 17, 368-376.

Felsenstein, J. (1985). Confidence limits on phylogenies: an approach using the bootstrap. Evolution 39, 783-791.

Felsenstein, J. (1997). An alternating least squares approach to inferring phylogenies from pairwise distances. Syst Biol 46, 101-111.

Fuerst, J. A., Hawkins, J. A., Holmes, A., Sly, L. I., Moore, C. J. \& Stackebrandt, E. (1993). Porphyrobacter neustonensis gen. nov., sp. nov., an aerobic bacteriochlorophyll-synthesizing budding bacterium from fresh water. Int J Syst Bacteriol 43, 125-134.

Ivanova, E. P., Bowman, J. P., Lysenko, A. M., Zhukova, N. V., Gorshkova, N. M., Kuznetsova, T. A., Kalinovskaya, N. I., Shevchenko, L. S. \& Mikhailov, V. V. (2005). Erythrobacter vulgaris sp. nov., a novel organism isolated from the marine invertebrates. Syst Appl Microbiol 28, 123-130.

Kates, M. (1986). Techniques of Lipidology. Amsterdam: Elsevier.

Kimura, M. (1980). A simple method for estimating evolutionary rates of base substitutions through comparative studies of nucleotide sequences. J Mol Evol 16, 111-120.

Kwon, K. K., Woo, J.-H., Yang, S.-H., Kang, J.-H., Kang, S. G., Kim, S.-J., Sato, T. \& Kato, C. (2007). Altererythrobacter epoxidivorans gen. nov., sp. nov., an epoxide hydrolase-active, mesophilic marine bacterium isolated from cold-seep sediment, and reclassification of Erythrobacter luteolus Yoon et al. 2005 as Altererythrobacter luteolus comb. nov. Int J Syst Evol Microbiol 57, 2207-2211.

Lau, K. W., Ng, C. Y., Ren, J., Lau, S. C., Qian, P. Y., Wong, P. K., Lau, T. C. \& Wu, M. (2005). Owenweeksia hongkongensis gen. nov., sp. nov., 
a novel marine bacterium of the phylum 'Bacteroidetes'. Int J Syst Evol Microbiol 55, 1051-1057.

Lee, K.-B., Liu, C.-T., Anzai, Y., Kim, H., Aono, T. \& Oyaizu, H. (2005). The hierarchical system of the 'Alphaproteobacteria': description of Hyphomonadaceae fam. nov., Xanthobacteraceae fam. nov. and Erythrobacteraceae fam. nov. Int J Syst Evol Microbiol 55, 1907-1919.

Lee, Y. S., Lee, D.-H., Kahng, H.-Y., Kim, E. M. \& Jung, J. S. (2010). Erythrobacter gangjinensis sp. nov., a marine bacterium isolated from seawater. Int J Syst Evol Microbiol 60, 1413-1417.

MacDonell, M. T., Singleton, F. L. \& Hood, M. A. (1982). Diluent composition for use of API $20 \mathrm{E}$ in characterizing marine and estuarine bacteria. Appl Environ Microbiol 44, 423-427.

Mesbah, M., Premachandran, U. \& Whitman, W. B. (1989). Precise measurement of the $\mathrm{G}+\mathrm{C}$ content of deoxyribonucleic acid by highperformance liquid chromatography. Int J Syst Bacteriol 39, 159-167.

Nedashkovskaya, O. I., Kim, S. B., Han, S. K., Lysenko, A. M., Rohde, M., Zhukova, N. V., Falsen, E., Frolova, G. M., Mikhailov, V. V. \& Bae, K. S. (2003). Mesonia algae gen. nov., sp. nov., a novel marine bacterium of the family Flavobacteriaceae isolated from the green alga Acrosiphonia sonderi (Kütz) Kornm. Int J Syst Evol Microbiol 53, 1967-1971.

Saitou, N. \& Nei, M. (1987). The neighbor-joining method: a new method for reconstructing phylogenetic trees. Mol Biol Evol 4, 406-425.

Sasser, M. (1990). Identification of bacteria by gas chromatography of cellular fatty acids, MIDI Technical Note 101. Newark, DE: MIDI Inc.

Shiba, T. \& Simidu, U. (1982). Erythrobacter longus gen. nov., sp. nov., an aerobic bacterium which contains bacteriochlorophyll $a$. Int J Syst Bacteriol 32, 211-217.

Shrout, J. D., Scheetz, T. E., Casavant, T. L. \& Parkin, G. F. (2005), Isolation and characterization of autotrophic, hydrogen-utilizing, perchlorate-reducing bacteria. Appl Microbiol Biotechnol 67, 261-268.

Smibert, R. M. \& Krieg, N. R. (1994). Phenotypic characterization. In Methods for General and Molecular Bacteriology, pp. 607-654. Edited by P. Gerhardt, R. G. E. Murray, W. A. Wood \& N. R. Krieg. Washington, DC: American Society for Microbiology.

Tamura, K., Peterson, D., Peterson, N., Stecher, G., Nei, M. \& Kumar, S. (2011). MEGA5: molecular evolutionary genetics analysis using maximum likelihood, evolutionary distance, and maximum parsimony methods. Mol Biol Evol 28, 2731-2739.

Thompson, J. D., Gibson, T. J., Plewniak, F., Jeanmougin, F. \& Higgins, D. G. (1997). The CLUSTAL_X windows interface: flexible strategies for multiple sequence alignment aided by quality analysis tools. Nucleic Acids Res 25, 4876-4882.

Xu, M. S., Xin, Y. H., Yu, Y., Zhang, J. L., Zhou, Y. G., Liu, H. C., Tian, J. S. \& Li, Y. (2010). Erythrobacter nanhaisediminis sp. nov., isolated from marine sediment of the South China Sea. Int J Syst Evol Microbiol 60, 2215-2220.

Yoon, J.-H., Kim, H., Kim, I.-G., Kang, K. H. \& Park, Y.-H. (2003). Erythrobacter flavus sp. nov., a slight halophile from the East Sea in Korea. Int J Syst Evol Microbiol 53, 1169-1174.

Yoon, J.-H., Kang, K. H., Oh, T.-K. \& Park, Y.-H. (2004). Erythrobacter aquimaris sp. nov., isolated from sea water of a tidal flat of the Yellow Sea in Korea. Int J Syst Evol Microbiol 54, 1981-1985.

Yoon, J.-H., Oh, T.-K. \& Park, Y.-H. (2005). Erythrobacter seohaensis sp. nov. and Erythrobacter gaetbuli sp. nov., isolated from a tidal flat of the Yellow Sea in Korea. Int J Syst Evol Microbiol 55, 71-75.

Yurkov, V., Stackebrandt, E., Holmes, A., Fuerst, J. A., Hugenholtz, P., Golecki, J., Gad'on, N., Gorlenko, V. M., Kompantseva, E. I. \& Drews, G. (1994). Phylogenetic positions of novel aerobic, bacteriochlorophyll a-containing bacteria and description of Roseococcus thiosulfatophilus gen. nov., sp. nov., Erythromicrobium ramosum gen. nov., sp. nov., and Erythrobacter litoralis sp. nov. Int J Syst Bacteriol 44, 427-434.

ZoBell, C. E. (1941). Studies on marine bacteria. I. The cultural requirements of heterotrophic aerobes. J Mar Res 4, 42-75. 